\title{
Molecular Characterization of Associated Pathogens in Febrile Patients during Inter-Epidemic Periods of Urban Arboviral Diseases in Tapachula Southern Mexico
}

\author{
Geovana Calvo-Anguiano ${ }^{1,+}$, José de Jesús Lugo-Trampe ${ }^{1,+}$, Gustavo Ponce-García ${ }^{2}$, Angel Lugo-Trampe ${ }^{3}$, \\ Laura Elia Martinez-Garza ${ }^{1}$ D , Marisol Ibarra-Ramirez ${ }^{1}$, Luis Daniel Campos-Acevedo ${ }^{1}{ }^{(D)}$, \\ Sandra Caballero-Sosa ${ }^{4}$, Alan Esteban Juache-Villagrana ${ }^{2}$, Ildefonso Fernández-Salas ${ }^{2,5}$, \\ Adriana Elizabeth Flores-Suarez ${ }^{2}$ (D), Iram Pablo Rodriguez-Sanchez ${ }^{2}$ (D) \\ and Karina del Carmen Trujillo-Murillo ${ }^{3, *(\mathbb{D})}$
}

check for

updates

Citation: Calvo-Anguiano, G.;

Lugo-Trampe, J.d.J.; Ponce-García, G. Lugo-Trampe, A.; Martinez-Garza,

L.E.; Ibarra-Ramirez, M.;

Campos-Acevedo, L.D.;

Caballero-Sosa, S.; Juache-Villagrana,

A.E.; Fernández-Salas, I.; et al.

Molecular Characterization of Associated Pathogens in Febrile Patients during Inter-Epidemic Periods of Urban Arboviral Diseases in Tapachula Southern Mexico.

Pathogens 2021, 10, 1450.

https://doi.org/10.3390/

pathogens 10111450

Academic Editors: Sheng-Fan Wang,

Wen-Hung Wang and

Arunee Thitithanyanont

Received: 8 October 2021

Accepted: 29 October 2021

Published: 8 November 2021

Publisher's Note: MDPI stays neutral with regard to jurisdictional claims in published maps and institutional affiliations.

Copyright: (C) 2021 by the authors. Licensee MDPI, Basel, Switzerland. This article is an open access article distributed under the terms and conditions of the Creative Commons Attribution (CC BY) license (https:// creativecommons.org/licenses/by/ $4.0 /)$
1 Departamento Genética, Facultad de Medicina, Universidad Autónoma de Nuevo Leon, Av. Francisco I. Madero S/N, Mitras Centro, Monterrey 64460, Nuevo Leon, Mexico; gcalvo.ang@gmail.com (G.C.-A.); lugotramjose@hotmail.com (J.d.J.L.-T.); laelmar@yahoo.com.mx (L.E.M.-G.); m.ibarrar25@gmail.com (M.I.-R.); luisdanielc@yahoo.com (L.D.C.-A.)

2 Facultad de Ciencias Biologicas, Universidad Autonoma de Nuevo Leon, Av. Pedro de Alba S/N, Ciudad Universitaria, San Nicolas de los Garza 66455, Nuevo Leon, Mexico; gponcealfa@gmail.com (G.P.-G.); alan.juache@gmail.com (A.E.J.-V.); ildefonso.fernandezsl@uanl.edu.mx (I.F.-S.); adrflores@gmail.com (A.E.F.-S.); iramrodriguez@gmail.com (I.P.R.-S.)

3 Facultad de Medicina Humana "Dr. Manuel Velasco Suárez", Campus IV, Universidad Autónoma de Chiapas, Tapachula 30792, Chiapas, Mexico; angel.lugo@unach.mx

4 Clínica Hospital Dr. Roberto Nettel Flores, Instituto de Seguridad y Servicios Sociales de los Trabajadores del Estado, Av. Tuxtepec y Oaxaca S/N, Francisco Villa, Tapachula 30740, Chiapas, Mexico; sandyluzcs@hotmail.com

5 Centro de Investigación y Desarrollo en Ciencias de la Salud, Universidad Autónoma de Nuevo León, Av. Mutualismo, Monterrey 64460, Nuevo León, Mexico

* Correspondence: karina.murillo@unach.mx

+ These two authors contributed equally to this work.

\begin{abstract}
Emerging and re-emerging vector-borne infections are a global public health threat. In endemic regions, fever is the main reason for medical attention, and the etiological agent of such fever is not usually identified. In this study, non-specific febrile pathogens were molecularly characterized in serum samples from 253 patients suspected of arbovirus infection. The samples were collected in the southern border region of Mexico from April to June 2015, and February to March 2016. ZIKV, CHIKV, DENV, leptospirosis, and rickettsiosis were detected by qPCR and nested PCR to identify flavivirus and alphavirus genera. The results indicated that $71.93 \%$ of the samples were positive for CHIKV, $0.79 \%$ for ZIKV, and $0.39 \%$ for DENV, with the number positive for CHIKV increasing to $76.67 \%$ and those positive for ZIKV increasing to $15.41 \%$ under the nested PCR technique. Leptospira Kmetyi was identified for the first time in Mexico, with a prevalence of $3.16 \%$. This is the first report of ZIKV in Mexico, as well the first detection of the virus in early 2015. In conclusion, the etiological agent of fever was determined in $94 \%$ of the analyzed samples.
\end{abstract}

Keywords: Arbovirus; Chikungunya; ZIKA; Leptospira; Flavivirus; Alphavirus; Mexico

\section{Introduction}

Arbovirus is manifested as a wide variety of clinical symptoms in the host that can range from asymptomatic or oligosymptomatic infection to even death [1,2]. During the acute phases of arboviruses such as dengue fever (DENV), chikungunya (CHIKV), and zika (ZIKV), the clinical manifestations are similar [3-7]. This fact complicates correct identification. There are also reports of coinfection, which, coupled with temporal or geographical clinical variations, makes differential diagnosis even more challenging [1]. 
In addition to the complexity of clinical diagnosis, arboviruses coexist with several pathogens that cause febrile diseases, such as leptospirosis and rickettsiosis, which are also regionally endemic [8-10]. Therefore, it is essential to understand the origins of febrile reactions to identify and determine the level of transmission of each disease and to correlate different clinical profiles to estimate the true magnitude of the problem and thus provide specific information for epidemiological surveillance, as well as establish timely specific patient management.

Since disease patterns and the spread of infections change over time, it is important to increase access to relevant epidemiological information, provide alternative diagnostic methods, and expand the evidence needed for decisions related to preventive and diagnostic measures. In this study, pathogens that cause febrile symptoms were molecularly characterized in serum samples from patients with symptoms (such as chikungunya disease in the southern border city of Tapachula, Chiapas, Mexico).

\section{Results}

We analyzed 253 samples from patients with the suggestive clinical presentation of arbovirus infection from the Dr. Roberto Nettel Hospital. Two hundred and six samples were obtained in April-June 2015, and 47 in February-March 2016, in several locations near Tapachula, Chiapas State, Mexico. Detailed patient clinical and demographic data are provided in Figure 1, Tables S1 and S2 (Supplementary Material). In total, 169 (66.8\%) were female and $84(32.2 \%)$ were male, with ages ranging from 7 to 74 years and a mean age of 39.4 years. Of the total samples, $72(28.45 \%)$ corresponded to the $41-50$-year-old age group. Distribution by sex was unequal, showing a male/female ratio of 0.49 . We determined that $76.67 \%(\mathrm{n}=194)$ of sera were positive for CHIKV, and $15.41 \%(\mathrm{n}=39)$ were positive for ZIKV, highlighting the presence of coinfections in $1.98 \%(n=5)$ of CHIKV /ZIKV samples. Other pathogens analyzed presented a prevalence of $3.16 \%(n=8)$ for Leptospira, $0.40 \%$ $(\mathrm{n}=1)$ for DENV, and 6.32\% $(\mathrm{n}=16)$ negative results. In the first period (April-June 2015), 12 patients with ZIKV were detected (three patients were detected in April). Moreover, eight patients with leptospirosis were detected.

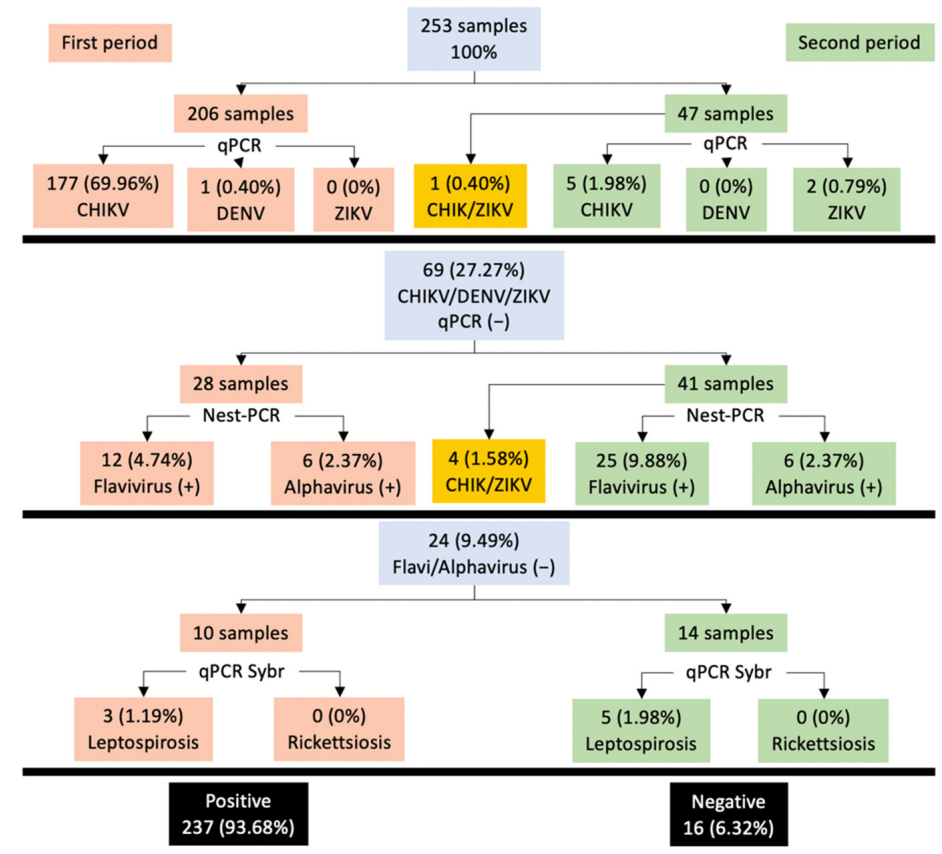

Figure 1. Epidemiological data were obtained for arboviruses and other pathogens. Gray boxes represent the total samples analyzed in each segment: (A) CHIKV/DENV/ZIKV, qPCR; (B) Flavi/Alphavirus, nested PCR; (C) Leptospira/Rickettsia, qPCR SybrGreen; orange and green boxes represent the samples collected in the two different periods (April-June 2015, and February-March 2016); the black boxes are the total positive and negative samples identified. 


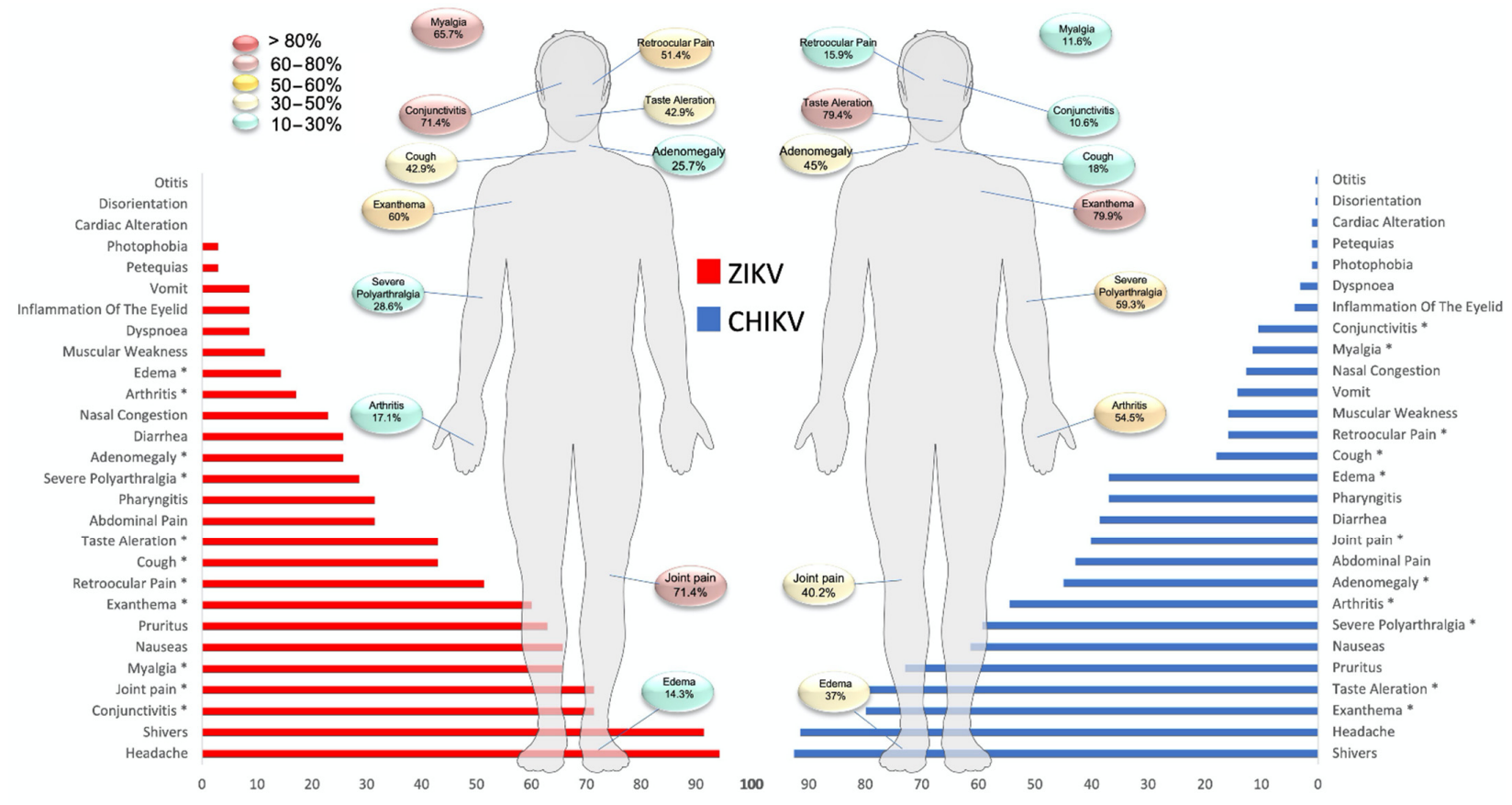

Figure 2. Comparison of clinical variables between the groups, CHIKV and ZIKV. ZIKV, Zika virus; CHIKV, chikungunya virus. ${ }^{\text {a }} \mathrm{ZIKV}+$ vs. CHIKV+. ${ }^{*} p<0.05$. Fisher's exact test.

The clinical descriptions of patients infected with ZIKV and CHIKV are shown in Figure 2 and Table S3 (supplementary). The mean number of days between the onset of symptoms and consultation was 3 to 4 , with no difference between $\mathrm{ZIKV}+$ and CHIKV+. However, most of the patients $(6 / 8)$ with leptospirosis experienced 6 or more days before symptom onset. Symptoms such as fever and headache were reported most frequently $(>90 \%)$; however, there was no significant difference between the groups $(p>0.05)$. The symptoms that did show substantial differences between ZIKV+ and CHIKV+ patients included myalgia $(65.7 \%$ vs. $11.6 \%, p<0.01)$, mild-moderate arthralgia $(71.4 \%$ vs. $40.2 \%$, $p<0.01)$, severe polyarthralgia ( $28.6 \%$ vs. $59.3 \%, p<0.01)$, arthritis $(17.1 \%$ vs. $54.5 \%$, $p<0.01)$, retro-orbital pain $(51.4 \%$ vs. $15.9 \%, p<0.01)$, conjunctivitis $(71.4 \%$ vs. $10.6 \%$, $p<0.01)$, cough $(42.9 \%$ vs. $18 \%, p<0.01)$, taste alteration $(42.9 \%$ vs. $79.4 \%, p<0.01)$, rash ( $60 \%$ vs. $79.9 \%, p<0.05)$, adenomegaly ( $25.7 \%$ vs. $45 \%, p<0.05)$, and edema ( $14.3 \%$ vs. $37 \%$, $p<0.05)$.

Symptoms such as vomiting, photophobia, and petechiae were less frequent. Only $28.5 \%(10 / 35)$ of ZIKV-positive patients developed symptoms that met the standard case definitions of ZIKV disease. In patients with CHIKV, 16.9\% (32/189) presented symptoms that met the criteria for Chikungunya disease. For Group II, out of 47 patients, we recorded five CHIKV+ / ZIKV + coinfection cases.

On the other hand, patients detected to have leptospirosis presented more frequent symptoms such as fever, headache, mild-moderate arthralgia, pruritus, nausea, chills, and conjunctivitis.

\section{Discussion}

Between the years 2014 and 2016, ZIKV and CHIKV caused outbreaks throughout the South American continent. Since then, these viruses have been classified as a public health problem [11]. An important factor associated with these diseases is the presence and abundance of vector mosquitos; numerous Aedes aegypti populations are found in the region, and vector incrimination was demonstrated after the isolation of CHIKV and ZIKV from field mosquito collections $[6,12,13]$. The vertical transmission of DENV was also documented by Danis-Lozano et al. (2019) in an extensive egg survey from south Mexico states [14]. Equally relevant is leptospirosis, a neglected tropical disease with 
signs and symptoms similar to those of arboviruses. Leptospirosis is included among the 17 neglected tropical diseases categorized by the World Health Organization [15].

Various reports on CHIKV, within the same period and region [3,4], showed a low detection rate of $55.3 \%$ and $64 \%$, respectively, when using molecular methods. In this study, the detection rate was $88.83 \%(183 / 206)$. The same effect was observed with ZIKV, for which we reported $57.44 \%$ (27/47) prevalence, while Guerbois et al. [6] reported a percentage of $21 \%$. This difference may be because two molecular techniques (qPCR and nested PCR) were used in our study to increase diagnostic efficiency. However, although nested PCR is one of the most sensitive PCR techniques, it has a higher probability of false positives under two amplification cycles. Therefore, care must be taken to reduce potential cross- and carryover contamination, which are the main difficulties associated with this technique [16].

One of the details observed in our work when using the probe for ZIKV in qPCR was low specificity because, in a subsequent analysis, a discrepancy was found in the sequence used (Figure S1, supplementary). Although RT-qPCR probes are sensitive and specific, they often have delimiting factors. Previous studies have shown that sample processing and RNA extraction methods contribute significantly to false positive and negative results $[17,18]$. Similarly, some studies showed that sequence variation in viruses can affect detection by RT-qPCR [19]. According to the data observed in this study, in times of the emergence or reemergence of a pathogen, it is likely that qPCR assays will have specificity problems that must be addressed before such assays can be used as a reliable screening method.

In our study, three people infected with ZIKV were detected around the middle of April 2015, while the first three cases of ZIKV in Mexico were reported on 25 November 2015 [20]. The virus was already detected in mosquitoes in the states of San Luis Potosi and Tabasco at the beginning of the same year [21]. Similarly, molecular clock studies showed that the virus was already circulating undetected as early as 2014 in Mexico and Central America [22,23]. Therefore, our data provide the first evidence for the existence of this virus in Mexico following the second quarter of the year.

Another objective of our study was to broaden the search for other pathogens that present symptoms similar to arboviruses [9]. Surprisingly, we detected eight cases of leptospirosis in 24 samples that were negative for flaviviruses and alphavirus. This finding is notable because leptospirosis is a globally distributed disease with a much higher risk in rural areas and urban slums in tropical areas. Rodents, dogs, cattle, pigs, and other wild animals are vectors of this disease $[24,25]$. In this study, the few diagnosed patients did not show any specific clinical characteristics of the disease, supporting the disease's clinical similarities to other febrile illnesses [10]. In Mexico, studies on this disease are usually scarce, and the vast majority are retrospective [26-29], which highlights the paucity of data on the surveillance and epidemiology of leptospirosis needed to address this neglected disease.

The species detected in our study was L. kmetyi, with $87.38 \%$ identity, a finding that has already been reported by some studies [30-32] (Figure S2, supplementary). However, most reported cases of leptospirosis are due to L. interrogans, L. kirschneri, and L. noguchii [33]. In some studies, the pathogenicity of L. kmetyi, which lacks most pathogenic-specific proteins and is not highly virulent in humans, was questioned [34]. Other studies classified L. kmetyi as a cause of disease in humans since L. kmetyi was isolated from symptomatic patients $[30,35,36]$. This study demonstrates, for the first time, the presence of L. kmetyi in patients from the border region of Mexico. This information provides important data for further investigations. More studies are needed to determine the serological and molecular characteristics of this strain and its distribution in Mexico, as well as explore the relationship between L. kmetyi and its possible role in human infection. We hope that this information will help create awareness about leptospirosis as an important emerging, neglected, tropical disease. 
Regarding the standard clinical characteristics reported for CHIKV [37] and ZIKV [38], our data were very similar for CHIKV, with fever, arthralgia, chills, headache, rash, pruritus, nausea, arthritis, abdominal pain, diarrhea, pharyngitis, and edema being the main symptoms, as also reported by previous studies [3,4]. Taste disturbances, pharyngitis, and other symptoms were rarely described. For ZIKV, fever, headache, chills, arthralgia, conjunctivitis, nausea, myalgia, pruritus, rash, retro-orbital pain, and abdominal pain have been previously reported by other working groups $[5,6,39,40]$.

As mentioned before, it is known that these two infections have similar clinical presentations; however, we detected some differences in their clinical manifestations. For ZIKV, symptoms included myalgia, mild-moderate arthralgia, retro-orbital pain, conjunctivitis, and cough. For CHIKV, severe polyarthralgia, arthritis, and abnormal taste were significantly different clinical symptoms between the two diseases. Despite these findings, when evaluating the clinical characteristics simultaneously, there is a considerable overlap of symptoms. This finding concludes that these signs or symptoms in isolation or as a group can increase the complexity of specific viral diagnosis.

Finally, despite the use of the different diagnostic techniques described above, 15 cases were negative for the aforementioned pathogens, which may have been due to a low viral load/bacterial load. This opens a path to search for other endemic pathogens in the region and develop panels for better identification [10,41]. Furthermore, although RT-qPCR is usually sufficiently specific and sensitive for virus identification, it is preferable to evaluate and optimize the assay with updated strains of the region being studied to reduce false-negative cases [42].

\section{Materials and Methods}

\subsection{Biological Material}

Serum samples were obtained from 253 patients from the Dr. Roberto Nettel Flores ISSSTE General Hospital in the city of Tapachula, Chiapas. The samples came from patients with febrile symptoms suspected of arbovirosis. After obtaining the sera, the samples were stored in $1.5 \mathrm{~mL}$ microtubes at a temperature of $-80^{\circ} \mathrm{C}$, corresponding to two periods: April-June 2015, and February-March 2016.

\subsection{Nucleic Acid Extraction}

RNA was extracted from $140 \mu \mathrm{L}$ of serum with a QIAamp Viral RNA Mini kit from Qiagen (cat \#52906). DNA was extracted from $50 \mu \mathrm{L}$ of serum using a Qiagen Gentra ${ }^{\circledR}$ Puregene kit (\#158445). The different extractions were carried out according to the manufacturer's instructions. The extracted nucleic acids (RNA and DNA) were stored at $-80^{\circ} \mathrm{C}$ until use.

\subsection{Arbovirus Detection Performed by One-Step RT-qPCR}

Specific fluorescent assays were used to detect the presence of CHIKV, ZIKV, and DENV1-4. The primers/probes used for the detection of emerging arboviruses are described in Table 1. Final concentrations of the primers and probes for CHIKV, ZIKV, and DENV1-4 were set at 20 $\times$. RT-qPCR assays were carried out using a StepOnePlus device (Thermo Fisher Scientific, Waltham, MA, USA). A QuantiTect Probe RT-qPCR 1× (Qiagen, Valencia, CA, USA) was used with $1 \mu \mathrm{L}$ of a $20 \times$ mix of primers/probes and $5 \mu \mathrm{L}$ of RNA at a concentration of 30-500 ng in a volume of $20 \mu \mathrm{L}$ under the following conditions: $30 \mathrm{~min}$ at $50{ }^{\circ} \mathrm{C}, 15 \mathrm{~min}$ at $95^{\circ} \mathrm{C}, 45$ cycles of $15 \mathrm{sec}$ at $94{ }^{\circ} \mathrm{C}$, and $60 \mathrm{sec}$ at $60^{\circ} \mathrm{C}$. Data collected from the RT-qPCR assays were analyzed using system software. Samples that reached cycle threshold values $(\mathrm{Ct})$ below 40 were established as positive. 
Table 1. Primers/probes used in this study.

\begin{tabular}{|c|c|c|c|}
\hline Primer and Probe & Sequence $\left(5^{\prime}-3^{\prime}\right)$ & Target & Reference \\
\hline \multicolumn{4}{|l|}{ Probe } \\
\hline ZIKV 1086 & CCGCTGCCCAACACAAG & $\mathrm{E}$ & [43] \\
\hline ZIKV 1162c & CCACTAACGTTCTTTTGCAGACAT & $\mathrm{E}$ & [43] \\
\hline ZIKV 1107-FAM & FAM-AGCCTACCTTGACAAGCAGTCAGACACTCAA-TAMRA & E & [43] \\
\hline CHIK856 & ACCATCGGTGTTCCATCTAAAG & nsP1 & [3] \\
\hline CHIK962c & GCCTGGGCTCATCGTTATT & nsP1 & [3] \\
\hline CHIK908-FAM & FAM-ACAGTGGTTTCGTGTGAGGGCTAC-TAMRA & nsP1 & [3] \\
\hline DENV 10635 & GARAGACCAGAGATCCTGCTGTCT & $3^{\prime} \mathrm{UTR}$ & [44] \\
\hline DENV 10682 & ACCATTCCATTTTCTGGCGTT & $3^{\prime} \mathrm{UTR}$ & {$[44]$} \\
\hline DENV123-10663-FAM & FAM-AGCATCATTCCAGGCAC-MGB & $3^{\prime} \mathrm{UTR}$ & [44] \\
\hline DENV4-10663-FAM & FAM-AACATCAATCCAGGCAC-MGB & $3^{\prime} \mathrm{UTR}$ & This study \\
\hline \multicolumn{4}{|l|}{ Nested PCR } \\
\hline cFD2 & GTGTCCCAGCCGGCGGTGTCATCAGC & ns5 & [45] \\
\hline MAMD & AACATGATGGGRAARAGRGARAA & ns5 & [45] \\
\hline FS 778 & AARGGHAGYMCDGCHATHTGGT & ns5 & [45] \\
\hline ALPHA-1-Fod & TTTAAGTTTGGTGCGATGATGAAGTC & $\mathrm{nsP} 4$ & [46] \\
\hline ALPHA-1-Rev & GCATCTATGATATTGACTTCCATGTT & nsP4 & [46] \\
\hline ALPHA-2-Fod & GGTGCGATGATGAAGTCTGGGATGT & nsP4 & [46] \\
\hline ALPHA-2-Rev & CTATGATATTGACTTCCATGTTCAKCСA & nsP4 & [46] \\
\hline \multicolumn{4}{|l|}{ Sybr-Green } \\
\hline RICK-ADN-For & TATGCTTGCGGCTGTCGGTTCTC & gltA & [47] \\
\hline RICK-ADN-Rev & TTGCGGTAAGTTCGTAGTCTGCTTCTT & gltA & [47] \\
\hline LEP-ADN-For & AGCAGCCGCGGTAATACGTATGG & $16 \mathrm{~S}$ rRNA & [47] \\
\hline LEP-ADN-Rev & TTTAGGGCGTGGATTACTGGGG & $16 \mathrm{~S}$ rRNA & {$[47]$} \\
\hline
\end{tabular}

\subsection{Nested-PCR}

Samples negative for CHIKV, DENV1-4, and ZIKV according to the RT-PCR assays were subsequently subjected to nested-PCR to identify flaviviruses and alphaviruses with universal primers. First, the negative samples were converted to cDNA using a highcapacity RNA-to-cDNA kit (\# 4368814) according to the manufacturer's instructions. A set of previously described primers was used (Scaramozzino et al. 2001) for the nested-PCR flavivirus, which produced a $250 \mathrm{bp}$ amplicon in the first round and a $220 \mathrm{bp}$ amplicon in the second round (Table 1). For the first PCR, cFD2-MAMD primers were used with a GoTaq G2 Hot Start Polymerase reagent (\#M7405) at a final concentration of $3 \mathrm{mM} \mathrm{MgCl}_{2}$; for the second PCR, the primers cFD2-FS778 were used at a final concentration of $2 \mathrm{mM}$ $\mathrm{MgCl}_{2}$. The reaction conditions were as follows: $2 \mathrm{~min}$ at $95^{\circ} \mathrm{C}, 25$ cycles of $10 \mathrm{~s}$ at $95^{\circ} \mathrm{C}$, $15 \mathrm{~s}$ at $54{ }^{\circ} \mathrm{C}$, and $40 \mathrm{~s}$ at $72{ }^{\circ} \mathrm{C}$ (30 cycles for the second PCR). In both PCRs, 1 U GoTaq G2 Hot Start Polymerase and primers at $2 \mu \mathrm{M}$ were used.

For the alphavirus nested PCR, a set of previously described primers (Grywna et al., 2010) was used, which produced a $210 \mathrm{bp}$ amplicon in the first round and a $197 \mathrm{bp}$ amplicon in the second round (Table 1). For the first PCR, the primers ALPHA-1-Fod/ALPHA-1Rev were used with the GoTaq G2 Hot Start Polymerase reagent (\#M7405) at a final concentration of $3 \mathrm{mM} \mathrm{MgCl}_{2}$; for the second PCR, the primers ALPHA- 2-Fod/ALPHA-2Rev were used at a final concentration of $2 \mathrm{mM} \mathrm{MgCl}_{2}$. The reaction conditions for the first PCR were as follows: $5 \mathrm{~min}$ at $95^{\circ} \mathrm{C}$ and 40 cycles of $10 \mathrm{~s}$ at $95^{\circ} \mathrm{C}, 30 \mathrm{~s}$ at $55^{\circ} \mathrm{C}$, and $30 \mathrm{~s}$ at $72{ }^{\circ} \mathrm{C}$. The second PCR conditions were $5 \mathrm{~min}$ at $95^{\circ} \mathrm{C}$ and 35 cycles of $10 \mathrm{~s}$ at $95^{\circ} \mathrm{C}, 30 \mathrm{~s}$ at $60{ }^{\circ} \mathrm{C}$, and $30 \mathrm{~s}$ at $72{ }^{\circ} \mathrm{C}$. In both PCRs, $1 \mathrm{U}$ GoTaq G2 Hot Start Polymerase and primers at $2 \mu \mathrm{M}$ were used.

\subsection{Identification of Leptospirosis and Rickettsiosis}

Negative samples in the previous tests were subjected to the identification of leptospirosis and rickettsiosis via qPCR with SYBR green, which used primers designed by Garcia-Ruiz et al., 2016 (Table 1). Maxima SYBR Green/ROX qPCR Master Mix was used at 1X (\#K0221) along with $50 \mathrm{uM}$ primers and $5 \mu \mathrm{L}$ of DNA in a volume of $25 \mu \mathrm{L}$. The reaction 
conditions for the first PCR were $2 \mathrm{~min}$ at $50{ }^{\circ} \mathrm{C}, 10 \mathrm{~min}$ at $95^{\circ} \mathrm{C}$, and 50 cycles of $15 \mathrm{~s}$ at $95^{\circ} \mathrm{C}$ with $60 \mathrm{~s}$ at $60^{\circ} \mathrm{C}$.

\subsection{Sequencing and BLAST}

PCR products from nested-PCR and qPCR with SYBR green were sequenced bidirectionally using the same primers and BigDye version 3.1 (Applied Biosystems, Foster City, CA, USA) according to the manufacturer's instructions. After purification, the products were sequenced on an ABI Prism 3130 Genetic Analyzer (Applied Biosystems). The sequences obtained were then compared with those of other flaviviruses, alphaviruses, and leptospiral sequences using the BLASTn program (available online: blast.ncbi.nlm.nih.gov / Blast.cgi; accessed on 8 October 2021).

\subsection{Statistical Analysis}

The statistical analysis was performed with IBM SPSS program version 23. Clinical and biological characteristics were compared using a $\mathrm{Chi}^{2}$ test. Student's $t$-test was used for normally distributed quantitative variables. Descriptive statistics were performed for the laboratory results. Variables with a $p$-value $<0.05$ were considered significant.

\section{Conclusions}

Ultimately, diagnosis was achieved in $94 \%$ of cases using different diagnostic techniques. This study is the first to identify the presence of ZIKV at the beginning of 2015. This study is also the first to report the presence of L. kmetyi in the southern border region of Mexico.

Supplementary Materials: The following are available online at https:/ /www.mdpi.com/article/ 10.3390/pathogens10111450/s1, Table S1: Demographic data of 253 patients included in this study, Table S2: Demographic information of pathogen localities in febrile patients, Table S3: Comparison of clinical variables between the CHIKV and ZIKV groups, Figure S1: Alignment primers/probes for $\mathrm{ZIKV}$, and Figure S2: Multiple alignment of leptospira species.

Author Contributions: Conceptualization, K.d.C.T.-M., G.P.-G. and G.C.-A.; data curation, J.d.J.L.-T., A.L.-T., M.I.-R. and L.D.C.-A.; formal analysis, J.d.J.L.-T., G.C.-A. and L.E.M.-G.; funding acquisition, L.D.C.-A.; investigation, J.d.J.L.-T., S.C.-S., G.C.-A., K.d.C.T.-M., I.P.R.-S. and A.L.-T.; methodology, G.C.-A., J.d.J.L.-T. and A.E.J.-V.; supervision, G.P.-G., G.C.-A., L.D.C.-A., S.C.-S. and K.d.C.T.-M.; validation, I.F.-S., A.E.F.-S. and M.I.-R.; visualization, J.d.J.L.-T., A.L.-T. and A.E.J.-V.; writingoriginal draft preparation, J.d.J.L.-T., G.C.-A., L.E.M.-G., I.P.R.-S. and S.C.-S.; writing-review and editing, G.P.-G., I.F.-S., A.E.F.-S., A.L.-T. and K.d.C.T.-M. All authors have read and agreed to the published version of the manuscript.

Funding: This work was supported by the Consejo Nacional de Ciencia y Tecnología (CONACyT). Fondo Institucional para el Desarrollo Científico, Tecnológico y de Innovación FORDECYTPRONACES (CF-MG-20191021151912477-514867), awarded to Daniel Campos-Acevedo.

Institutional Review Board Statement: This study was conducted according to the guidelines of the Declaration of Helsinki and approved by the Research Ethical Committee and Research Committee of the Universidad Autonoma de Chiapas (Project \#03/CMD/RPR/010/16).

Informed Consent Statement: All participants read the statement of purpose of the survey and provided informed consent.

Data Availability Statement: Data are available upon request to the authors.

Conflicts of Interest: The authors declare no conflict of interest.

\section{References}

1. Ananth, S.; Shrestha, N.; Treviño, J.A.T.; Nguyen, U.-S.; Haque, U.; Angulo-Molina, A.; Lopez-Lemus, U.A.; Lubinda, J.; Sharif, R.M.; Zaki, R.A.; et al. Clinical Symptoms of Arboviruses in Mexico. Pathogens 2020, 9, 964. [CrossRef]

2. Carteaux, G.; Maquart, M.; Bedet, A.; Contou, D.; Brugières, P.; Fourati, S.; Cleret de Langavant, L.; De Broucker, T.; BrunBuisson, C.; Leparc-Goffart, I.; et al. Zika Virus Associated with Meningoencephalitis. N. Engl. J. Med. 2016, 374, 1595-1596. [CrossRef] [PubMed] 
3. Danis-Lozano, R.; Díaz-González, E.E.; Trujillo-Murillo, K.D.C.; Caballero-Sosa, S.; Sepúlveda-Delgado, J.; Malo-García, I.R.; Canseco-Ávila, L.M.; Salgado-Corsantes, L.M.; Domínguez-Arrevillaga, S.; Torres-Zapata, R.; et al. Clinical characterization of acute and convalescent illness of confirmed chikungunya cases from Chiapas, S. Mexico: A cross sectional study. PLoS ONE 2017, 12, e0186923. [CrossRef] [PubMed]

4. Galán-Huerta, K.A.; Martínez-Landeros, E.; Delgado-Gallegos, J.L.; Caballero-Sosa, S.; Malo-García, I.R.; Fernández-Salas, I.; Ramos-Jiménez, J.; Rivas-Estilla, A.M. Molecular and Clinical Characterization of Chikungunya Virus Infections in Southeast Mexico. Viruses 2018, 10, 248. [CrossRef]

5. Garza-González, E.; Mendoza-Olazarán, S.; Roman-Campos, R.; Téllez-Marroquín, R.; Saldívar-Rodríguez, D.; Soria-López, J.A.; Guzman, A.; Flores-Treviño, S.; Camacho-Ortiz, A. Rapid Spread of an Ongoing Outbreak of Zika Virus Disease in Pregnant Women in a Mexican Hospital. Braz. J. Infect. Dis. 2017, 21, 554-556. [CrossRef]

6. Guerbois, M.; Fernandez-Salas, I.; Azar, S.R.; Danis-Lozano, R.; Alpuche-Aranda, C.M.; Leal, G.; Garcia-Malo, I.R.; Diaz-Gonzalez, E.E.; Casas-Martinez, M.; Rossi, S.L.; et al. Outbreak of Zika Virus Infection, Chiapas State, Mexico, 2015, and First Confirmed Transmission by Aedes Aegypti Mosquitoes in the Americas. J. Infect. Dis. 2016, 214, 1349-1356. [CrossRef]

7. Muller, D.A.; Depelsenaire, A.C.; Young, P.R. Clinical and Laboratory Diagnosis of Dengue Virus Infection. J. Infect. Dis. 2017, 215, S89-S95. [CrossRef] [PubMed]

8. Hunsberger, S.; Ortega-Villa, A.M.; Powers, J.H., 3rd; Rincón León, H.A.; Caballero Sosa, S.; Ruiz Hernández, E.; Nájera Cancino, J.G.; Nason, M.; Lumbard, K.; Sepulveda, J.; et al. Patterns of Signs, Symptoms, and Laboratory Values Associated with Zika, Dengue, and Undefined Acute Illnesses in a Dengue Endemic Region: Secondary Analysis of a Prospective Cohort Study in Southern Mexico. Int. J. Infect. Dis. 2020, 98, 241-249. [CrossRef] [PubMed]

9. Mwachui, M.A.; Crump, L.; Hartskeerl, R.; Zinsstag, J.; Hattendorf, J. Environmental and Behavioural Determinants of Leptospirosis Transmission: A Systematic Review. PLoS Negl. Trop. Dis. 2015, 9, e0003843. [CrossRef] [PubMed]

10. Moreira, J.; Barros, J.; Lapouble, O.; Lacerda, M.V.G.; Felger, I.; Brasil, P.; Dittrich, S.; Siqueira, A.M. When Fever Is Not Malaria in Latin America: A Systematic Review. BMC Med. 2020, 18, 294. [CrossRef]

11. Rodriguez-Morales, A.J.; Villamil-Gómez, W.E.; Franco-Paredes, C. The arboviral burden of disease caused by co-circulation and co-infection of dengue, chikungunya and Zika in the Americas. Travel Med. Infect. Dis. 2016, 14, 177-179. [CrossRef]

12. Roundy, C.; Azar, S.; Rossi, S.; Huang, J.; Leal, G.; Fernandez-Salas, I.; Vitek, C.; Paploski, I.; Kitron, U.; Ribeiro, G.; et al. Variation in Aedes aegypti Mosquito Competence for Zika Virus Transmission. Emerg. Infect Dis. 2017, 23, 625-632. [CrossRef] [PubMed]

13. Díaz-González, E.; Kautz, T.; Dorantes-Delgado, A.; Malo-García, I.; Laguna-Aguilar, M.; Langsjoen, R.; Chen, R.; Auguste, D.; Sánchez-Casas, R.; Danis-Lozano, R.; et al. First Report of Aedes aegypti Transmission of Chikungunya Virus in the Americas. Am. J. Trop Med. Hyg. 2015, 93, 1325-1329. [CrossRef]

14. Danis-Lozano, R.; Díaz-González, E.; Malo-García, I.; Rodríguez, M.; Ramos-Castañeda, J.; Juárez-Palma, L.; Ramos, C.; LópezOrdóñez, T.; Mosso-González, C.; Fernández-Salas, I. Vertical transmission of dengue virus in Aedes aegypti and its role in the epidemiological persistence of dengue in Central and Southern Mexico. Trop Med. Int. Health 2019, 24, 1311-1319. [CrossRef] [PubMed]

15. Karpagam, K.B.; Ganesh, B. Leptospirosis: A Neglected Tropical Zoonotic Infection of Public Health Importance-An Updated Review. Eur. J. Clin. Microbiol. Infect. Diseases 2020, 39, 835-846. [CrossRef] [PubMed]

16. da Silva, M.A.L.; Soares, C.R.P.; Medeiros, R.A.; Medeiros, Z.; de Melo, F.L. Optimization of single-tube nested PCR for the diagnosis of visceral leishmaniasis. Exp. Parasitol. 2013, 134, 206-210. [CrossRef] [PubMed]

17. Burchill, S.; Lewis, I.J.; Selby, P. Improved methods using the reverse transcriptase polymerase chain reaction to detect tumour cells. Br. J. Cancer 1999, 79, 971-977. [CrossRef]

18. Keilholz, U.; Willhauck, M.; Rimoldi, D.; Brasseur, F.; Dummer, W.; Rass, K.; de Vries, T.; Blaheta, J.; Voit, C.; Lethé, B.; et al Reliability of Reverse Transcription-Polymerase Chain Reaction (RT-PCR)-Based Assays for the Detection of Circulating Tu-mour Cells: A Quality-Assurance Initiative of the EORTC Melanoma Cooperative Group. Eur. J. Cancer. 1998, 34, 750-753. [CrossRef]

19. Kamau, E.; Agoti, C.N.; Lewa, C.S.; Oketch, J.; Owor, B.E.; Otieno, G.P.; Bett, A.; Cane, P.A.; Nokes, D.J. Recent sequence variation in probe binding site affected detection of respiratory syncytial virus group B by real-time RT-PCR. J. Clin. Virol. 2017, 88, 21-25. [CrossRef]

20. Kindhauser, M.K.; Allen, T.; Frank, V.; Santhana, R.S.; Dye, C. Zika: The origin and spread of a mosquito-borne virus. Bull. World Health Organ. 2016, 94, 675-686C. [CrossRef] [PubMed]

21. Díaz-Quiñonez, J.A.; López-Martínez, I.; Torres-Longoria, B.; Vázquez-Pichardo, M.; Cruz-Ramírez, E.; Ramírez-González, J.E.; Ruiz-Matus, C.; Kuri-Morales, P. Evidence of the presence of the Zika virus in Mexico since early 2015. Virus Genes 2016, 52, 855-857. [CrossRef] [PubMed]

22. Metsky, H.C.; Matranga, C.B.; Wohl, S.; Schaffner, S.F.; Freije, C.A.; Winnicki, S.M.; West, K.; Quigley, J.E.; Baniecki, M.L.; Gladden-Young, A.; et al. Zika virus evolution and spread in the Americas. Nature 2017, 546, 411-415. [CrossRef]

23. Thézé, J.; Li, T.; du Plessis, L.; Bouquet, J.; Kraemer, M.U.; Somasekar, S.; Yu, G.; de Cesare, M.; Balmaseda, A.; Kuan, G.; et al. Genomic Epidemiology Reconstructs the Introduction and Spread of Zika Virus in Central America and Mexico. Cell Host Microbe 2018, 23, 855-864.e7. [CrossRef]

24. Costa, F.; Hagan, J.; Calcagno, J.; Kane, M.; Torgerson, P.; Martinez-Silveira, M.S.; Stein, C.; Abela-Ridder, B.; Ko, A.I. Global Morbidity and Mortality of Leptospirosis: A Systematic Review. PLoS Negl. Trop. Dis. 2015, 9, e0003898. [CrossRef] 
25. Guernier, V.; Goarant, C.; Benschop, J.; Lau, C.L. A systematic review of human and animal leptospirosis in the Pacific Islands reveals pathogen and reservoir diversity. PLoS Negl. Trop. Dis. 2018, 12, e0006503. [CrossRef]

26. Yescas-Benítez, J.E.; Perez, N.R.; Montiel-Díaz, H.; Valladares-Carranza, B.; Peláez-Acero, A.; Morales-Ubaldo, A.L.; Bastida, A.Z. Comportamiento Epidemiológico de La Leptospirosis En México Durante El Periodo 2013-2019. Rev. Salud Pública 2020, 22, e202. [CrossRef]

27. Sandoval-Carrillo, A.A.; Salas-Pacheco, J.M.; Antuna-Salcido, E.I.; Castro-Martínez, K.S.; Ortiz-Montaño, D.S.; Beristain-Garcia, I.; Alvarado-Retana, H.M.; Ramos-Nevarez, A.; Salas-Pacheco, S.M.; Sifuentes-Alvarez, A.; et al. Leptospira infection in people in the city of Durango, Mexico: A cross sectional study. J. Int. Med. Res. 2021, 49, 3000605211004020. [CrossRef]

28. Galarde-López, M.; Bobadilla-Del Valle, M.; Sánchez-Zamorano, L.M.; Ordaz-Vázquez, A.; Velazquez-Meza, M.E.; So-beranisRamos, O. High Exposure to Pathogenic Leptospires by the Population Residing in Dairy Farms in Hidalgo, Mexico. Braz. J. Microbiol. 2021, 52, 1013-1019. [CrossRef]

29. Sánchez-Montes, S.; Espinosa-Martínez, D.V.; Ríos-Muñoz, C.A.; Berzunza-Cruz, M.; Becker, I. Leptospirosis in Mexico: Epidemiology and Potential Distribution of Human Cases. PLOS ONE 2015, 10, e0133720. [CrossRef]

30. Ali, M.R.M.; Safiee, A.W.M.; Yusof, N.Y.; Fauzi, M.H.; Yean, C.Y.; Ismail, N. Isolation of Leptospira kmetyi from residential areas of patients with leptospirosis in Kelantan, Malaysia. J. Infect. Public Health 2018, 11, 578-580. [CrossRef]

31. Saito, M.; Miyahara, S.; Villanueva, S.Y.A.M.; Aramaki, N.; Ikejiri, M.; Kobayashi, Y.; Guevarra, J.P.; Masuzawa, T.; Gloriani, N.G.; Yanagihara, Y.; et al. PCR and Culture Identification of Pathogenic Leptospira spp. from Coastal Soil in Leyte, Philippines, after a Storm Surge during Super Typhoon Haiyan (Yolanda). Appl. Environ. Microbiol. 2014, 80, 6926-6932. [CrossRef]

32. Zaki, A.M.; Hod, R.; Shamsusah, N.A.; Isa, Z.M.; Bejo, S.K.; Agustar, H.K. Detection of Leptospira kmetyi at recreational areas in Peninsular Malaysia. Environ. Monit. Assess. 2020, 192, 703. [CrossRef] [PubMed]

33. Esteves, L.; Bulhões, S.M.; Branco, C.C.; Carreira, T.; Vieira, M.L.; Gomes-Solecki, M.; Mota-Vieira, L. Diagnosis of Human Leptospirosis in a Clinical Setting: Real-Time PCR High Resolution Melting Analysis for Detection of Leptospira at the Onset of Disease. Sci. Rep. 2018, 8, 9213. [CrossRef] [PubMed]

34. Picardeau, M. Virulence of the zoonotic agent of leptospirosis: Still terra incognita? Nat. Rev. Microbiol. 2017, 15, 297-307. [CrossRef]

35. Bourhy, P.; Storck, C.H.; Theodose, R.; Olive, C.; Nicolas, M.; Hochedez, P.; Lamaury, I.; Zinini, F.; Brémont, S.; Landier, A.; et al. Serovar Diversity of Pathogenic Leptospira Circulating in the French West Indies. PLoS Negl. Trop. Dis. 2013, 7, e2114. [CrossRef]

36. Meny, P.; Menéndez, C.; Quintero, J.; Hernández, E.; Ríos, C.; Balassiano, I.T.; Trindade, C.N.D.R.; Vital-Brazil, J.M.; Ramos, T.M.V.; Ashfield, N.; et al. Characterization of Leptospira isolates from humans and the environment in Uruguay. Rev. Inst. Med. Trop. São Paulo 2017, 59, e79. [CrossRef]

37. Staples, J.E.; Breiman, R.F.; Powers, A.M. Chikungunya Fever: An Epidemiological Review of a Re-Emerging Infectious Disease. Clin. Infect. Dis. 2009, 49, 942-948. [CrossRef] [PubMed]

38. Musso, D.; Gubler, D.J. Zika Virus. Clin. Microbiol. Rev. 2016, 29, 487-524. [CrossRef]

39. Duffy, M.R.; Chen, T.-H.; Hancock, W.T.; Powers, A.M.; Kool, J.L.; Lanciotti, R.S.; Pretrick, M.; Marfel, M.; Holzbauer, S.; DuBray, C.; et al. Zika Virus Outbreak on Yap Island, Federated States of Micronesia. N. Engl. J. Med. 2009, 360, 2536-2543. [CrossRef]

40. Belaunzarán-Zamudio, P.F.; Mateja, A.; Guerra-De-Blas, P.D.C.; Rincón-León, H.A.; Navarro-Fuentes, K.; Ruiz-Hernández, E.; Caballero-Sosa, S.; Camas-Durán, F.; Priego-Smith, Z.; Nájera-Cancino, J.G.; et al. Comparison of clinical characteristics of Zika and dengue symptomatic infections and other acute illnesses of unidentified origin in Mexico. PLoS Negl. Trop. Dis. 2021, 15, e0009133. [CrossRef]

41. Liu, J.; Ochieng, C.; Wiersma, S.; Ströher, U.; Towner, J.S.; Whitmer, S.; Nichol, S.T.; Moore, C.C.; Kersh, G.J.; Kato, C.; et al. Development of a TaqMan Array Card for Acute-Febrile-Illness Outbreak Investigation and Surveillance of Emerging Pathogens, Including Ebola Virus. J. Clin. Microbiol. 2016, 54, 49-58. [CrossRef] [PubMed]

42. Corman, V.M.; Rasche, A.; Baronti, C.; Aldabbagh, S.; Cadar, D.; Reusken, C.B.; Pas, S.D.; Goorhuis, A.; Schinkel, J.; Molenkamp, R.; et al. Assay optimization for molecular detection of Zika virus. Bull. World Health Organ. 2016, 94, 880-892. [CrossRef] [PubMed]

43. Lanciotti, R.S.; Kosoy, O.L.; Laven, J.J.; Velez, J.O.; Lambert, A.J.; Johnson, A.J.; Stanfield, S.M.; Duffy, M.R. Genetic and Serologic Properties of Zika Virus Associated with an Epidemic, Yap State, Micronesia, 2007. Emerg. Infect. Dis. 2008, 14, 1232-1239. [CrossRef]

44. Gurukumar, K.R.; Priyadarshini, D.; Patil, J.A.; Bhagat, A.; Singh, A.; Shah, P.S.; Cecilia, D. Development of real time PCR for detection and quantitation of Dengue Viruses. Virol. J. 2009, 6, 10. [CrossRef]

45. Scaramozzino, N.; Crance, J.-M.; Jouan, A.; DeBriel, D.A.; Stoll, F.; Garin, D. Comparison of Flavivirus Universal Primer Pairs and Development of a Rapid, Highly Sensitive Heminested Reverse Transcription-PCR Assay for Detection of Flaviviruses Targeted to a Conserved Region of the NS5 Gene Sequences. J. Clin. Microbiol. 2001, 39, 1922-1927. [CrossRef]

46. Grywna, K.; Kupfer, B.; Panning, M.; Drexler, J.F.; Emmerich, P.; Drosten, C.; Kümmerer, B.M. Detection of All Species of the Genus Alphavirus by Reverse Transcription-PCR with Diagnostic Sensitivity. J. Clin. Microbiol. 2010, 48, 3386-3387. [CrossRef] [PubMed]

47. Garcia-Ruiz, D.; Martínez-Guzmán, M.A.; Cárdenas-Vargas, A.; Marino-Marmolejo, E.; Gutiérrez-Ortega, A.; González-Díaz, E.; Morfin-Otero, R.; Rodríguez-Noriega, E.; Pérez-Gómez, H.; Elizondo-Quiroga, D. Detection of dengue, west Nile virus, rickettsiosis and leptospirosis by a new real-time PCR strategy. SpringerPlus 2016, 5, 671. [CrossRef] [PubMed] 